\title{
Italy picks businessman to head space agency
}

Italian scientists are worried that a shake-up of the nation's space agency will put commercial and defence interests ahead of research.

Prime Minister Silvio Berlusconi is in the process of replacing the president of the Italian Space Agency. He is removing the agency's current head, astrophysicist Giovanni Bignami, and installing business executive Enrico Saggese, who heads the space division at Finmeccanica, Italy's largest aerospace firm.

The move has met with concern from the agency's independent scientific and technical council, most of whom signed a letter to the government last week asking it to reconsider. "We are worried that the scientific programme will be under-funded or cancelled in the next couple of years," says Guido Visconti, an atmospheric physicist at the University of L'Aquila and a member of the council.

The shake-up began in early July when six of seven members of the space agency's governing council resigned to allow the Berlusconi government "the greatest level of freedom" in determining the agency's future. Under its own rules, the mass resignation made the agency ungovernable and Italy's council of ministers is now seeking to install Saggese as a commissioner - an interim position that would give him complete control. A similar set of circumstances surrounded the resignation of the agency's previous president, aerospace engineer Sergio Vetrella, in 2006

Berlusconi came to office in May, and the latest political manoeuvring is seen by some as an attempt to strengthen the space agency's ties with industry. Others think that the government may be moving the agency towards providing more military surveillance and other applications. The government did not respond to Nature's requests for comment, but has previously denied that it is planning such changes.

Bignami has only been the incumbent for a year, but has been credited with raising the profile of research, which takes up just $10-15 \%$ of the agency's roughly $€ 700$ million (US $\$ 1.1$ billion) annual budget. Coming from a research position at the Institute for Advanced Study in
Pavia, he is widely seen as more science-savvy than his predecessors. And he has given scientists more control of how research funds are spent by instituting a series of review panels. "We think he did a great job," says Pietro Ubertini, director of the Institute of Space Astrophysics and Cosmology in Bologna. "He gave us full freedom to choose the scientific programme."

Bignami is also popular with Italy's foreign partners as, for example, he helped to coordinate data-sharing between international weather satellites. Italy will chair the next triennial European Space Agency ministerial meeting in November, and Bignami's replacement "could be very disruptive to overall planning", warns Bo Andersen, director general of the Norwegian Space Centre.

However, not everyone is concerned. "As far as science is concerned, I don't think it's a big issue," says Guido Chincarini, an astrophysicist at the University of Milan, who points out that the proposed deputy commissioner, Piero Benvenuti, is an astronomer at the University of Padova. He is also one of the resigning directors.

The government has less than a month to install Saggese, but for now, Bignami continues to run the agency. "No one has asked me to resign," he says. "And therefore I have not." Geoff Brumfiel, additional reporting by

Faye Fornasier

\section{School chemistry off-limits to terrorism suspect}

\begin{abstract}
A British judge has ruled that a terrorism suspect cannot take secondary-school level courses in chemistry and human biology.

In a first-of-a-kind ruling, High

Court judge Stephen Silber said that the courses would put the suspect who is referred to as A.E. for privacy reasons - in a "substantially stronger position" to carry out chemical and biological attacks.

But scientists are unconvinced. An AS level in human biology is unlikely to provide much in the way of skills to a potential terrorist, says Charles Penn, a molecular microbiologist at the University of Birmingham. "I'm pretty sceptical that this is a real, tangible risk," he says.
\end{abstract}

The ruling paints a "misleading image of school chemistry being a subject of particular value to potential terrorists", says Richard Pike, chief executive of the Royal Society of Chemistry. "There is nothing on the AS-level chemistry course that cannot be found easily on the web and through other means," he says.

A.E. is an Iraqi national with alleged ties to terrorist groups including Al-Qaeda in Iraq, according to the UK government. Since 2006 he has been subject to a 'control order', a special legal instrument that places limits on his freedoms, including his Internet use. He is subject to surveillance and must seek approval from the Home Office before undertaking coursework.

In September 2007, he asked for permission to enrol in AS-level courses in chemistry and human biology. In Iraq, A.E. had been training as a doctor and the courses were the first step in continuing his education, according to his solicitor, Mohammed Ayub, of Chambers Solicitors in Bradford. The Home Office denied his request, claiming that knowledge gained in the coursework could be used for terrorism. A.E. contested the decision in court, claiming that ASlevel courses were largely harmless (see Nature 450, 467; 2007).

The 15-page ruling, released on 21 July, upholds the Home Office's claim. Based in part on testimony from an anonymous security official known only as ' $X$ ', Justice Silber found that A.E. would gain expertise, particularly in using equipment, that might further terrorist activities. But Penn questions how useful the courses would be for a would-be terrorist.
Even university-level students would have trouble producing large quantities of a pathogen such as anthrax, he says, "they wouldn't have a clue where to start".

Silber also called into question A.E.'s previous medical training in Iraq, which had been a key part of A.E.'s argument - his lawyer maintained that the AS-level courses would review information he had already learned. Even if A.E. could learn new techniques from the courses, Ayub adds, he is under such tight scrutiny that he would be unable to do much. "The risk is negligible to nil," he says.

Ayub says that his client is "dismayed" by the ruling, and they are likely to decide whether to take the case to the Court of Appeal within the coming weeks. Geoff Brumfiel 